Naplyokov Yuriy Vasilievich, Master of Strategic Sciences, Master of Military Art and Science, senior lecturer of the department of training of peacekeeping personnel, National Defense University of Ukraine named after Ivan Chernyakhovsky, Colonel, postgraduate student of the Department of Management and Administration of Kharkov National University of Municipal Economy named after O. M. Beketov, 03049, Kyiv, Povitroflotsky Prospect, 28, tel.: +38 (098) 242 13 53, e-mail: designyon@gmail.com

ORCID: 0000-0002-0343-8337

\title{
Напльоков Юрій Васильович,
}

магістр стратегічних наук, магістр військових наук та військового мистеиттва, старший викладач кафедри підготовки миротворчого персоналу, Національний університет оборони України імені Іва-

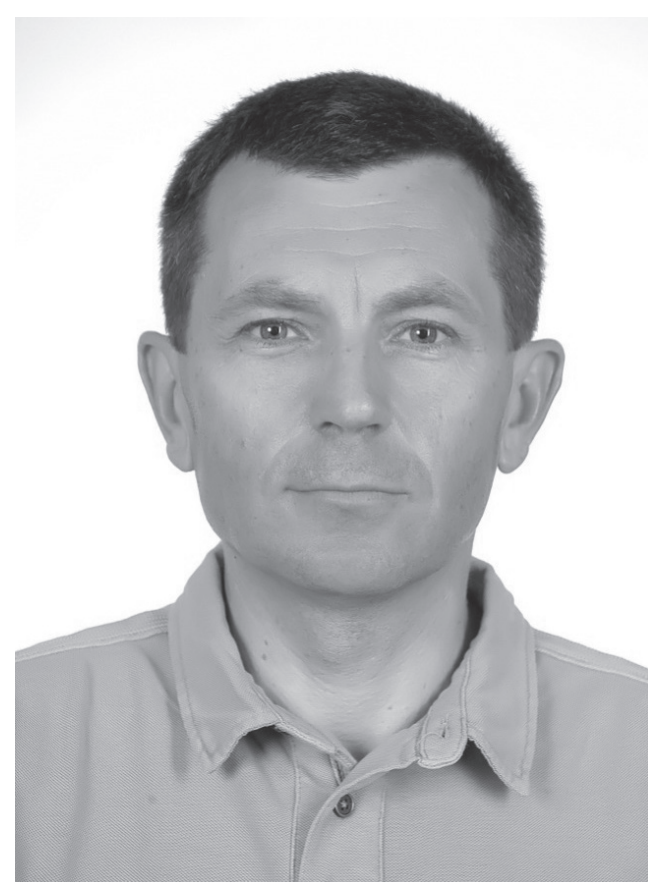
на Черняховського, полковник, аспірант кафедри менеджменту і адміністрування Харківського начіонального університету міського господарства імені О. М. Бекетова, 03049, м. Київ, Повітрофлотський проспект, 28, тел.: +38 (098) 24213 53, е-таil: designyon@gmail.com

ORCID: 0000-0002-0343-8337

\section{Наплёков Юрий Васильевич,}

магистр стратегческих наук, магистр военных наук и военного искусства, старший преподаватель кафедры подготовки миротворческого персонала, Национальный университет обороны Украины имени Ивана Черняховского, полковник, аспирант кафедры менеджмента и администрирования Харьковского национального университета городского хозяйства имени А. Н. Бекетова, 03049, г. Киев, Воздухофлотский проспект, 28, тел.: +38 (098) 242 13 53, e-mail: designyzn@gmail.com

\section{A MODEL OF DELEGATION OF LEADERSHIP BETWEEN THE STATE AUTHORITY AND THE CIVIL SOCIETY}

Abstract. This article introduces the model of delegation of leadership between the state authority (SA) and the civil society (CS) in order to make state governance effective in conditions of the complex and dynamic environment. The model has to help to identify the degree of involvement of the SA and the CS 
in leadership of the state according to complexity, uncertainty and dynamics of changes of the environment and the state (system).

Participation of the SA and the CS in state leadership is critical to make the system smart and effective. It requires proper applying of leadership power, changing of leadership styles, and, eventually, the organizational structure based on the situation. The changeable environment requires adaptation of the system and/or shaping of the environment in order to establish equilibrium between the system and the environment. It is possible to do through proper participation of the SA and the CS in the decision-making process (DMP). Together they have to identify roots of the problem, analyze it and make decisions to adapt the system and/ or influence the environment by various synchronized and coordinated activities based on synergy effect.

In the changeable environment, a level of participation of the SA and the CS in the state leadership should be flexible. Complete decentralization or centralization with identified rules and regulations may not allow delegating leadership properly between the SA and the CS in order to make the system effective. Moreover, even right combination of the SA and the CS may not provide success because of lack of readiness for their cooperation. It can depend on national culture, a government system, willingness of people to be involved in the leadership process, and other features. Also often only a smaller part of population is active and ready for innovations and change. To collect and educate these people require efforts based on devotion to national values, beliefs, and altruism. However, in a transition period these notions are also changeable and may not present a real "national fundament". All reasons above force finding a practical approach when, where and how to divide leadership power between the SA and the CS in the changeable environment.

Keywords: leadership, state authority, civil society, system, environment, equilibrium, coefficient, thinking, effectiveness.

\section{МОДЕЛЬ ДЕЛЕГУВАННЯ КЕРІВНИЦТВА МІЖ ДЕРЖАВНОЮ ВЛАДОЮ ТА ГРОМАДЯНСЬКИМ СУСПІЛЬСТВОМ}

Анотація. Представлено модель делегування керівництва між державною владою (ДВ) та громадянським суспільством (ГС), щоб зробити державне управління ефективним в умовах складного та динамічного середовища. Ця модель сприятиме виявленню ступеня залучення ДВ та ГС до керівництва держави відповідно до складності, невизначеності та динаміки змін середовища та держави (системи).

Участь ДВ та ГС у керівництві державою є критичною, щоб зробити систему розумною та ефективною. Це вимагає належного застосування лідерської сили, зміни стилів керівництва та, нарешті, організаційної структури, засновуючись на ситуації. Змінне середовище вимагає адаптації системи та/ або формування середовища для встановлення рівноваги між системою та середовищем. Це можливо завдяки належній участі ДВ та ГС у процесі прийняття рішень (ППР). Разом вони повинні визначити коріння проблеми, 
аналізувати її та виробляти рішення щоб адаптувати систему та/або вплинути на середовище різними синхронними та узгодженими діями на основі синергетичного ефекту.

У змінному середовищі рівень участі ДВ та ГС у керівництві державою має бути гнучким. Повна децентралізація або централізація з визначеними правилами та положеннями може не дозволити належно делегувати керівництво між ДВ та ГС, щоб зробити систему ефективною. Навіть правильна комбінація ДВ та ГС не може забезпечити успіх через відсутність готовності до їх співпраці. Це може залежати від національної культури, системи держави, бажання людей брати участь у процесі керівництва та інших особливостей. Часто лише менша частина населення активна і готова до інновацій та змін. Щоб зібрати та навчити цих людей, потрібні зусилля, що базуються на відданості національним цінностям, переконанням та альтруїзмі. Проте в перехідний період ці поняття також є змінними і можуть не представляти реальний “національний фундамент”.

Усі наведені причини зумовлюють пошук практичного підходу, коли, де і як розділяти лідерську владу між ДВ та ГС у змінному середовищі.

Ключові слова: лідерство, державна влада, громадянське суспільство, система, середовище, рівновага, коефіцієнт, мислення, ефективність.

\section{МОДЕЛЬ ДЕЛЕГИРОВАНИЯ РУКОВОДСТВА МЕЖДУ ГОСУДАРСТВЕННОЙ ВЛАСТЬЮ И ГРАЖДАНСКИМ ОБЩЕСТВОМ}

Аннотация. Представлена модель делегирования руководства между государственной властью (ГВ) и гражданским обществом (ГО), чтобы сделать государственное управление эффективным в условиях сложной и динамичной среды. Эта модель должна способствовать выявлению степени привлечения ГВ и ГО к руководству государства в соответствии со сложностью, неопределенностью и динамикой изменения среды и государства (системы).

Участие ГВ и ГО в руководстве государством является критическим, чтобы сделать систему разумной и эффективной. Это требует надлежащего применения лидерской силы, изменения стилей руководства и, наконец, организационной структуры, основываясь на ситуации. Изменяющаяся среда требует адаптации системы и/или формирования среды для установления равновесия между системой и средой. Это возможно благодаря надлежащему участию ГВ и ГО в процессе принятия решений (ППР). Вместе они должны определить корни проблемы, анализировать ее и вырабатывать решения, чтобы адаптировать систему и / или повлиять на среду различными синхронизованными и согласованными действиями на основе синергетического эффекта.

В изменяющейся среде уровень участия ГВ и ГО в руководстве государством должно быть гибким. Полная децентрализация или централизация с определенными правилами и положениями может не позволить должным делегировать руководство между ГВ и ГО, чтобы сделать систему эффектив- 
ной. Правильная комбинация ГВ и ГО не может обеспечить успех из-за отсутствия готовности к их сотрудничеству. Это может зависеть от национальной культуры, системы государства, желания людей участвовать в процессе руководства и других особенностей. Часто лишь меньшая часть населения активна и готова к инновациям и изменениям. Чтобы собрать и научить этих людей, нужны усилия, основанные на преданности национальным ценностям, убеждениях и альтруизме. Однако в переходный период эти понятия также являются переменными и могут не представлять реальный “национальный фундамент".

Все перечисленные причины обусловливают поиск практического подхода, когда, где и как разделять лидерскую власть между ГВ и ГО в изменяющейся среде.

Ключевые слова: лидерство, государственная власть, гражданское общество, система, среда, равновесие, коэффициент, мышление, эффективность.

Target setting. Technological development, globalization, increased communication, growing difference between national and corporate interests can make the environment complex, dynamic and unpredictable. These conditions force seeking new leadership approaches to maintain system adaptable, agile, and effective. This problem requires researching in the context of when, whom and how the state power should be delegated.

Analysis of the recent research and publications. Continuous debates on numerous reforms, propositions of governance models, and focus on decentralization have not answered the question how to lead the state effectively [2, p. 5]. In the rapid changeable environment so called "new public management" emerged in the 1980s and early 1990s as "not a reform of the traditional public administration, but a transformation of the public sector and its relationship with government and society" [3, p. 135].
Combination of the SA and the CS, as two main leadership parts of the system, is decisive in order to provide effective governance in the complex and dynamic environment. The SA associates with all official organizations and agencies that shaped by law. The CS presents different nongovernmental, nonprofit public local, national and international organizations, private firms and groups. Inter organizational relations between the network of providers and those who govern them are critical [4].

Decentralization can be considered as a delegation of leadership power from the SA to the CS. It can facilitate building "good governance" [5] that should work effectively in the complex environment. However, decentralization does not mean always increase of system effectiveness especially in conditions of low readiness of cooperation between the SA and the CS. Also for complex societies, "centralization and control emerge as circumstances require" $[6$, 
p. 37-38]. Nevertheless, absolute centralize leadership may be destructive in the changeable environment. Therefore, to find a harmony between the SA and the CS in complex societies may require promoting asymmetrical and balanced decentralization that "should not be seen as a win-lose or one-sided relation" [7, p. 25]. Moreover, change of the environment requires adaptation of the society. However, human factor is naturally stable and its change takes efforts and time. Thus, under conditions mentioned above distribution of leadership power between the SA and the CS is critical in order to lead the system effectively in the complex and dynamic environment.

The purpose of the article is to create a leadership model for the system to operate in the complex and changeable environment based on proper delegation of leadership power between the SA and the CS. Many Western countries have found their ways to satisfy people and maintain national interests. A proposed leadership model is critical for the system because a long-term search of a governance model in the transitional phase can decrease effectiveness of the system or even destroy it.

The statement of basic materials. Applying of philosophy of public administration may help to understand the essence of effective governance. "Public administration as a process is a unique phenomenon that has significant differences in different countries of the world... Each individual state, like every individual, is a unique social phenomenon" [8]. Even in the democratic European administrative space "we need to maintain a broad range and diversity of models" [9, p. 8]. Therefore, the most important not a fixed public administrative model, but an approach how to lead the system. A model of the delegation of leadership power between the SA and the CS should be flexible because of the changeable environment and features of different countries and regions that based on beliefs, values cultures, and religions. Consequently, it defines participation of the SA and the CS in the decision-making process (DMP) that have to establish system balance as satisfaction of human needs.

The needs can be divided into physiological needs, safety needs, love and belongingness needs, esteem needs, and self-actualization needs [10]. Deficiency needs are biological needs arising from being deprived of something. Growth needs (social) arise as a desire of individual growth. The needs are subjective and depend on a particular person. They develop throughout life and have a temporary attachment. In addition, any one satisfied need creates a new one. This gave the economics a reason to formulate the law of growth needs. It expresses the objective need for the growth of human needs (quantitatively and qualitatively) with the social and economic progress of the society.

To analyze relationships between the SA and the CS is important to review theories that describe the origin of the state and explain contradictions between them. According to the conflict theory, the state appeared because of the needs of individuals and a society. Integration theories explain that the state arose because of the needs of society and not the ambitions of individuals or subgroups [11, p. 15].

Coordination and direction of different parts of complex societies by the 
government [6, p. 34] may create tensions between the SA and the CS. The state is based on "divided interests, on domination and exploitation, on coercion, and is primarily a stage for power struggles" [11, p. 16-17]. The state serves to maintain the privilege position of the SA that is mainly based on "the exploitation and economic degradation of the masses" [12, p. 181-2]. Moreover, the governing body that provides goods or services has coercive power that is "an inevitable covariable of an essential benefit" [13, p. 83].

Satisfaction of needs forms a set of interests and influences human behavior. Needs expand, multiply and complicate, and change not only quantitatively, but also qualitatively. Needs generate motives such as unplanned motives, low (wishes, desires, and aspirations), and high (interest, ideal, orientation) motives. Motivation is a collection of motives that determine the behavior of the individual. Initiation of the need of change is based on knowledge that can convince and force people for change.

A difference between expectations and achievements can define satisfaction. This notion is relative and may look different for people.In spite of this, it is possible to assume that there is a certain condition when the system is balanced and people are satisfied. To define this condition can help to create a universal model that will determine a required level of delegation of leadership power between the SA and the CS in any environment and for any system.

It is possible to apply leadership theories and rules to describe relationships between the SA and the CS like two leadership subjects - a leader and subordinates. The SA may have politically ambitious people who can satisfy own ambitions more than needs of others. Members of the CS are bigger in number but not so consolidated, active, motivated, and politically directed as the SA. Together, the SA and the CS should operate through the DMP in order to maintain national interests and satisfy people by influencing the system and/ or the environment.

System adaptation and/or shaping of the environment are two possible ways to maintain equilibrium between changeable the system and the environment. The degree of their combination proposes an approach to restore equilibrium based on available ways and means. In many cases, adaptation may be a primary to make the system effective in spite of mental and structural models that are created based on not always topical past experience.

To analyze the problem of the effective governance is important to see the system and the environment as a single whole that generates development and life. Like two competitive poles, they exist in their combination, influence on each other, compete, and resist changing in order to preserve their physical and mental structures. Eventually, the system and the environment strive to decrease conflict between each other through establishing of equilibrium. In fact, this process is endless. Established equilibrium has to balance the system and provide its maximum effectiveness because the system does not spend additional energy to resist to the environment.

Resistance is a result of system reaction to the environmental change to secure its balance. The system protects own "center of gravity" as one of 
"primary sources of moral or physical strength, power and resistance" [14, p. IX], in order to be secured from any change. Establishment of a new equilibrium encompasses strategic, operational, and tactical levels as a system process of development. This process includes different planned activities to satisfy the system and the environment or establish equilibrium between them through the DMP based on balance of ends, ways and means in the framework of the edge risk or possible permissible risk $(\mathrm{EWM}+\mathrm{R})$ [15, p. 87]. Ends can be revised in order to maintain balance in the framework EWM+R and save system from destruction.

Constraints and quantity of variety are connected. The balanced participation of the CS in leadership may provide a required variety to deal with resistance of the system when change is required. "It is a relation between two sets, and occurs when the variety that exists under one condition is less than the variety that exists under another" [16, p. 127]. Delegation of leadership from the SA to the CS can satisfy this condition.

Changes in the system are critical to maintain its balance. Technological and economic development, globalization, and individual growth make the system and the environment complex and changeable. The problem is to monitor change of elements of the system and the environment, cooperate, and create a puzzle with "a nice picture". Change is natural because it is a source of energy that based on human physical and social domains. A human social domain is based on social rules of life that should provide balance of the system in a certain period. Rules are part of the system and their change requires applying information, knowledge, and wisdom as the highest decision-making level based on intuition, experience, and human satisfaction.

Change of one of elements of a social system may require change of others. One spiritual whole links people. "The whole is at a state of equilibrium if and only if each part is at a state of equilibrium in the conditions provided by the other part" [16, p. 83]. It is possible to suppose that equilibrium of the human system is more connected with psychological side when all parts, as a whole, share the same beliefs and values. It means the main effort can be directed to cultivate similar values and beliefs that are critical in the DMP.

Philosophically the notion of "all-in-one space" may present a combination of opposing the SA and the CS. It can explain the idea of leadership. "The spiritual principle determines the whole material world with all its forms and, therefore, is itself free from these forms. It is free of space and time; the beginning of immediate existence and the logical essence - will and idea are united in it inseparably; it is unconditionally a single and together universal being, a whole spirit..." [17, p. 142]. This spirit can reflect national identity, values, and beliefs. Low readiness of the CS to take part in the state leadership process and lack of wish of the SA to delegate power to the CS [18] can show absence of one whole in Ukraine.

To maintain the system effective in the complex and dynamic environment requires building a model of a learning organization [19, p. 3-4] that studies itself, the environment, and urgently makes corrections based on 
realistic feedback. This organization is agile, adaptable, and resilient enough to achieve an established goal. Members of this organization can equally take part in the DMP and implement decisions. Similar, cooperation between the SA and CS facilitates effective decisionmaking that allows properly adapting the system and influencing the environment. The CS opens the system through continuous feedback, learning, and creating conditions for critical, creative and system thinking. This leadership model allows minimizing influence of human biases and traps [20] on the DMP.

The CS, "public governance", decentralization and democracy are inevitable notions of a prosperous society that can resolve problems quickly. However, only $32 \%$ of Ukrainian population is ready to take part in problem solving of their community [18, p. 13]. Also, only $12 \%$ of population knows well about decentralization [18, p. 11]. The majority of population (67\%) does not feel real changes because of decentralization [18, p. 14-15].

The CS can influence political ambitions and directions of system development, but a low level of participation of the CS decreases effectiveness of the governance. In Ukraine it happens because of essential features in interactions between the SA and the CS such as:

1) lack of understanding of the mechanism of participation and a place of the CS in the governance in spite of wish of the CS to take part in political discussions and reform implementation;

2) the SC does not trust to the SA;

3) the SA is not ready to delegate an authority to the CS;
4) lack of communication between the SA and the CS.

Ukraine has a paradox: the CS is ready to participate in governance, but does not understand the role and ways of participation in the leadership process. Also, because the Ukrainian society does not trust to the politicians there is a tendency of decreasing of interest to the state policy from the CS (58\% to $52 \%$ ) and increased number of indifferent people to politics from $41 \%$ to $47 \%$ [21, p. 7]. Thus, as a result of a growing gap between the CS and the SA the system does not get realistic feedback and loses effectiveness.

The majority of Ukrainian population (60\% in 2015 and $64 \%$ in 2016) continues to consider the necessary reform of local self-government, but only $24 \%$ of them consider it to be absolutely necessary [21, p. 7]. It means the $\mathrm{CS}$ is ready to take part in the politics of Ukraine and the SA has to delegate a part of its power to it. Also, the overwhelming majority of the population, who at least knows about reform (61\%), believes that it goes slowly. Thus, reforms are not effective and the DMP goes wrong. It is possible to explain by breaks in feedback because of lack of involvement of the CS in the DMP. People do not feel themselves as members of one team. It decreases their wish to participate and be responsible for the process of state building. At the same time, $55 \%$ of populations consider the need of correction of the Constitution [21, p. 10]. In addition, consciousness and knowledge of the CS about cooperation with the SA in the framework of a democratic system are low.

According to the "Shadow Report" of the laboratory of legitimate initiatives 
[22], the reform of the Ukrainian public administration (UPA) shows that there are some success and also problems in reform implementation. In general, the UPA) is not a learning organization yet. In conditions of changeable and dynamic environment, the UPA as a system is not effective and cannot compete with developed Europium or American public administration models.

It does not mean the UPA on the wrong way of its development. It is just a process of searching and testing of an appropriate leadership model and its structure for Ukraine. But, there are obvious gaps in the work because of lack of system approach to understand the problem. There are no consolidated political leadership, a long-term strategic goal, and a gap between the DMP and the planning process, a weak legislation system in support of the reform in PA, weak communication lines, lack of professionals, a not enough level of computerization, weak feedback, and an assessment mechanism. All above make the UPA not effective. Thus, it is possible to observe that the UPA as a system is weak and cannot work effectively and maintain national interests properly especially in competitive conditions of a complex and changeable environment.

Applying of the notion of "entropy" can explain relationships between the system and the environment in order to build a model of effective leadership. Entropy can be considered as a characteristic of diversity of the system, since it is determined by the probabilities of realization of states and reaches its maximum on a uniform distribution (the maximum variety is when any state can be realized with equal probability), and the minimum - when any one state is realized with probability equal to 1 . Then the control consists in such a transformation of the set of states, as a result of which the probabilities of some (undesirable) controlled states decrease, and the probabilities of other (desirable) states increase, which ensures a lowering of the entropy. According to the law of Requisite Variety [16], this can be achieved by increasing of the diversity of the system that leads, under the condition of unequivocal leadership. Thus, to deal with increased complexity requires a diverse system under condition of one leadership. The CS can provide diversity and the SA - one leadership.

An open system has a tendency to decrease its entropy because of interaction with the environment and, therefore, to improve decision-making. Depending on the level of initial entropy and effectiveness of the decision-making approach entropy decreases in time [23]. The external environment has a certain level of residual entropy or undetermined information that is required for the DMP. The start of the DMP corresponds to the high level of informational entropy.

In conditions of the complex and dynamic environment flexible leadership can facilitate building a learning organization that is open for adaptation through an increased level of entropy. This organization has the highest level of democracy based on "public governance" and decentralization when everyone has an equal voice. It facilitates developing knowledge and, therefore, an ability to revise obsolete ideas and perceptions because knowledge proves the need of change. 
"Public governance" presents a participative type of leadership based on democracy. However, uncontrolled democracy can create anarchy when the system can lose its functionality. Environmental change influences the system and, eventually, changes its structure. In this case, an achievement of a certain critical level can require centralized (authoritative) type of leadership in order to make rapid vital decisions to save system functionality and accomplish a mission. Thus, the leadership process is flexible and depends on the environment.

The author supposes that to lead the system effectively means to create a learning organization that will maintain equilibrium between the system and the environment and achieve established goals. To lead the system properly requires quick reaction to change based on feedback, influence on political ambitions, speed of the DMP, and decision implementation. It is possible to achieve by a flexible delegation of leadership power between the CS and the SA. It may require structural change, revising of values, beliefs, and obsolete mental models [24] because in the new environment they do not support effective decisions anymore. Study and knowledge should force people for change through their participation in the DMP.

A coefficient of dynamic equilibrium (Keq) defines a level of equilibrium between the system and the environment [25, p. 8]. In its tern, it can determine a degree of delegation of leadership power between the SA and the CS in order to improve the DMP to maintain system balance. It should correspond to the optimal coefficient of dynamic equilibrium
Keq opt [24, p. 216] that provides maximum achievable system effectiveness in conditions of changeable environment.

The SA presents and mainly protects an existed governance system. The CS changes the system in order to satisfy human needs. Together they have to promote national interests. Degree of participation of the SA and the CS in leadership process can differ for regions or districts of one country because of features of values, beliefs, perceptions, culture, traditions, rules, norms, geographic and economic conditions, dialects, and other.

If equilibrium is destroyed because of different reasons, the situation becomes chaotic and the system starts looking for a new structure (order). It is like "a puzzle" when a decision-maker should collect parts of the puzzle in a right way and create "a picture" that should satisfy the system and the environment. It is a kind of bargaining and negotiation through using of different ways and means to get the best possible result for each side. There is the best combination of the negotiation. However, because the system and the environment are changeable to maintain this combination requires continuous leading the system based on decision-making.

The system fluctuates under environmental influence. If fluctuation of the system corresponds to fluctuation of the environment, they can produce resonance and a synergy effect. Also, a physical system can have as many resonant frequencies as it has degrees of freedom. It may require understanding each other through system openness and communication. To create resonance may mean change of something. Resonance can be a force for change 
that produces a new system structure through destruction of an obsolete one. It is a result of high frequency of fluctuation between the system and the environment or their "mutual agreement" to be on the same "wave" and understand each other.

Delay in system reaction to the environmental change $(\Delta T)[26$, p. 179] can define its effectiveness. It may create a conflict as a lack of step-by-step or "soft" adaptation based on system openness and realistic feedback. Proper participation of the SA and the CS in the DMP can decrease $\Delta \mathrm{T}$. Solving of growing conflict may require increased frequency of fluctuation of the SA $\left(F_{s a}\right)$ and the CS $\left(F_{c s}\right)$. Interaction between the SA and the CS, as a product of convergent and divergent processes [27] (fig. 1) should generate required decisions to solve the problem.

Points A and B (fig. 1, 2) show divergent and convergent processes. At the start of the DMP, the amplitude of fluctuation of functions $F_{s a}$ and $F_{c s}$ is high. To the end of the DMP convergent and divergent processes come closer and eventually the decision is made in the point of their convergence.
A level of participation of members of the system in negative and positive feedbacks may define system adaptability. The convergent process reflects negative feedback, as critical thinking in the DMP, and the divergent process - positive feedback, as creative thinking. System thinking should combine paradoxically different the SA with the CS. In general, it is a leadership process with a certain level of delegation of power to each other.

In conditions of changeable environment $K_{e q}$ is equal to a level of delegation of leadership power and $K_{e q}=f\left(F_{s a}, F_{c s}\right)$. Thus, collaboration between SA and CS based on knowledge can be critical for timely response to environmental change. It may be a key notion to build a model of a learning organization that allows finding "a new order from the chaos" without conflicts. Hence, based on this it is possible to create a leadership model that can be applied to any governance levels: a parliament with opposing parties, regions, local communities with different interests and other.

The CS has certain ambitions and growth needs. Their realization means achievement of the $K_{\text {eq opt }}$, but on the new

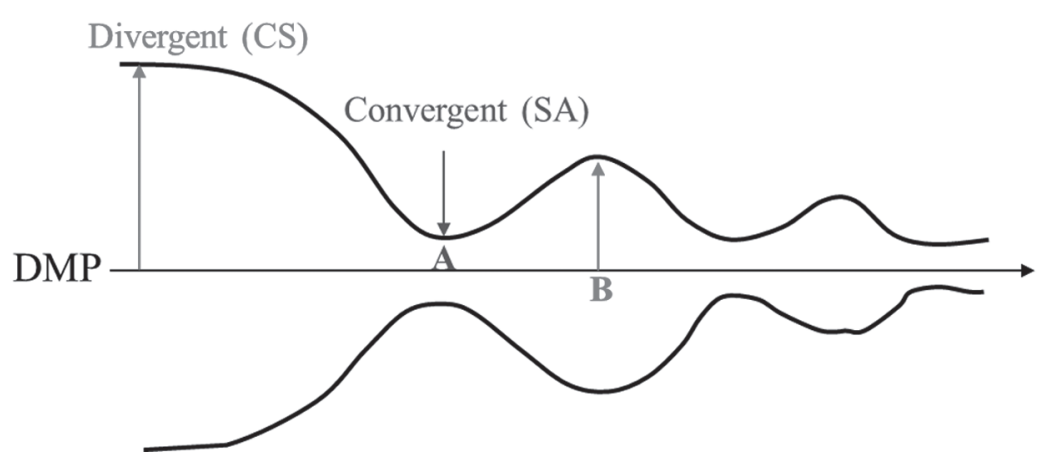

Fig. 1. Divergent and convergent interactions in the DMP between the SA and the CS Source: created by the author. 
level of development. It is a continuous process of system development when a next growth can break equilibrium between the system and the environment again. Frequency of fluctuation of the system $\left(F_{s}\right)$ and the environment $\left(F_{\text {env }}\right)$ may be limited. When they will achieve a certain possible maximum the system can be changed in order to restore equilibrium again or to achieve $K_{\text {eq opt }}$.

Assessment of the system can help to determine $K_{e q \text { opt }}$. A measure of effectiveness (MOE) answers the question - does the system do right things? A measure of performance (MOP) answers the question - does the system do it properly [28, p. 15-2]? MOE, as a level of realization of national (regional) values and beliefs, the future vision, and MOP, as a level of life, income, prosperity, security, may determine $K_{e q \text { opt }}$. The SA and the CS establish MOE and MOP as human satisfaction based on realization of their wishes, beliefs, values, and maintaining of other national interests. If there is no satisfaction the decision is wrong. MOE and MOP should support this condition. For example, if established MOE and MOP do not provide a desired and realistic level of life, people can consider them as wrong one.

MOE and MOP can differ for systems because of variety of reasons. MOE depends on the environment, state of the system (stable, unstable), position of the system in the framework of "time-space-force", mutual influence between the system and the environment. MOP depends on trust, unity of efforts, common interests, patriotism, openness, and other. The level of human satisfaction (Lhs), as a difference between expectations and results, can de- fine $K_{\text {eq opt }}$ for the system. Human satisfaction is a relative notion that is based on national traits, culture, perceptions, mentality, and other. In any case, it defines optimal equilibrium between the system and the environment: $K_{\text {eq opt }}=$ $=f(L h s)$. The Lhs can be assessed by MOE and MOP with value indicators.

Satisfaction of the SA and the CS may define balance of the system. It is possible to suppose that $K_{e q ~ o p t}$ is constant for any system and conditions because it is a characteristic of its balance. For instance, regions of one country are different because of environment (geographical location, climate, economical orientation, neighbors) and own characteristics (religions, language dialects, traditions, and rules), but to be balanced a regional community has to establish $K_{\text {eq opt }}$. Also the system can achieve $K_{e q c t}, K_{e q \text { min }}$, and $K_{\text {eq } \max }$ in which the system can decrease its effectiveness and achieve bifurcation points (changes). The model of delegation of leadership power has to facilitate successful leading the system based on four key points: $K_{e q \min }, K_{e q \text { c ct }}, K_{e q \text { opt }}$, and $K_{e q \max }$ [26, p. 180].

The leadership model includes the SA with state agencies and the CS with different non-state organizations. Ideally, all players have to work together in order to get a synergy effect. A leader should lead and synchronize them. The SA and the CS are parts of the leadership process. The SA should feel the $\mathrm{CS}$ and the CS should understand the SA and national interests. Both have to work together because of one goal - to maintain/improve a level of life (national interests). The SA and the CS are parts of one system that has to react quickly to any change in the system 
and/or in the environment. To do this the system should act with its certain frequency of fluctuation $\left(F_{s}\right)$ to the environmental fluctuation $\left(F_{\text {env }}\right)$. The SA and the CS fluctuate in a certain degree $\left(F_{s a}, F_{c s}\right)$ and together present fluctuation of the system $\left(F_{s}\right)$.

Frequency of fluctuation $F_{s}\left(F_{s a}, F_{c s}\right)$ and $F_{e n v}$ can define an approach for problem-solving. Based on $F_{s a}$ the SA should change leadership power, play with leadership styles, and eventually change system structure [1, p. 72]. $F_{c s}$ is more connected with $F_{e n v}$. The CS has to react to the environmental change through the SA. If Fenv is high, the CS should play a critical role in dealing with a change of the environment based on decentralization. It is a cycle process of reaction on change of the Env $\rightarrow$ the $\mathrm{CS} \rightarrow$ the SA.

It is possible to assume that functions of the SA and the CS have a deviation form and a certain normal line (fig. 2). The normal line is connected with system balance and effectiveness. Proper use of the combination of the SA and the CS may shift a normal line of the system to another level in order to respond to the environmental change. A normal line can correspond to a certain system structure.
Normal (optimal) leadership of the system (Snorm) means a level of combination of the SA and the CS in the given environment that should provide required system effectiveness and correspond to Keq opt when the system is balanced and effective. Snorm may shift to an authoritarian type of leadership (S1) when the SA is dominant or a democratic type (S2) when the CS plays primary role (fig. 2). Different positions of the leadership model can depend on the environment and speed of its change. It is possible to assume that sum of power of the SA and CS is equal to $1(\mathrm{SA}+\mathrm{CS}=1)$.

To lead the level of participation between the SA and the CS is decisive in order to react properly to changeable environment. However, both sides should balance and maintain the system on the level of Snorm. This level provides the most effective system functionality. It is a position that should be lead until the system with a current structure and technological development does not become obsolete. It corresponds to a change of the system structure as a third level of leadership approach [1, p. 72]. A new Snorm with new S1 and $\mathrm{S} 2$ means a shift of the system on the new technological and structural levels.

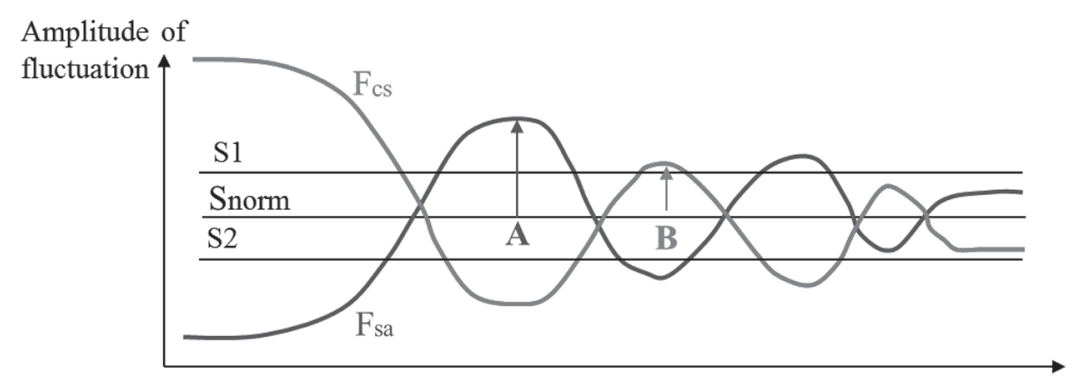

Fig. 2. Balance of leadership power between the SA and the CS Source: created by the author. 
An optimal combination between participations of the SA and the CS can provide maximum possible system effectiveness. It may be based on environmental and system conditions such as a geopolitical location, economic, culture, national perceptions, and others. Introduction of the notion of the level of involvement of SA $\left(L_{s a}\right)$ and the CS $\left(L_{c s}\right)$ in the state leadership process can help to analyze governance effectiveness.

The SA presents a centralized power and the CS - decentralized one. The proportion of their mutual involvement can be defined by the participative coefficient $-\mathrm{Cp}$. Thus, $\mathrm{Cp}=\mathrm{Lcs} /$ Lsa. If $\mathrm{Cp} \rightarrow 1$ the system is democratic and theoretically when $\mathrm{Cp}=1$ there is no leader at all. If $\mathrm{Cp} \rightarrow 0$ an authoritarian leader dominates. It is possible to accept that under condition $0,5 \leq \mathrm{Cp}<1$ the system is democratic and when $0<\mathrm{Cp}<0,5$ the system is the authoritarian one.

A necessity to open the system for adaptation and control it at the same time creates a paradox. In this situation a primary role can belong to leadership and understanding where, when, and who should lead the system. Thus, the task is to maintain $K_{\text {eq opt }}$ based on proper $\mathrm{Cp}$ that should be flexible and, therefore, different. It means establishment of long-term decentralization or centralization does not provide high system effectiveness.

The best $\mathrm{Cp}$ has to provide maximum system effectiveness when $K_{e q}=$ $=K_{\text {eq opt }}$. This condition defines the level of required $\mathrm{Cp}$ for the system in the current environment. Thus, $\mathrm{Cp}$ depends on the environment and Keq in a certain moment. Consequently, a level of system effectiveness $\left(L_{\text {sef }}\right)$ is a function of $K_{\text {eq opt }}$ and $K_{\text {eq opt }}$ is a function of Cp. Thus, $L_{\text {sef }}=f\left(K_{\text {eq opt }}(f(\mathrm{Cp}))\right.$.

Therefore, "Public governance" is not pure participation of the CS when $\mathrm{Cp}=1$ when there is no SA at all $\left(L_{s A}=0\right)$. Actually, it is an ideal model of a learning organization that adapts to the environment continuously. On one hand, a system, can change or disappear during adaptation. On the other hand, it can help to keep the system under strong environmental influence. If the task is to save the system functionality, the SA and the CS, both, have to take part in the governance process based on secured beliefs, values, ideology, and patriotism. If the task is to adapt the system, beliefs and values may be revised.

The SA and the CS have to take part in the DMP in order to make a decision that will satisfy regional and national interests. The leadership purpose is to establish $\mathrm{Cp}$ based on the situation or favorable moment in the framework of "time, space, and force". The task is to maintain $K_{\text {eq opt }}$ that will provide functionality of the system by timely implementation of change. A right $\mathrm{Cp}$ has to balance $\mathrm{EWM}+\mathrm{R}$ in the DMP. Regulation of $\mathrm{Cp}$ is flexible process that requires qualified leaders on local, regional, and governmental levels.

To make the governance effective can require:

For the CS:

1) to create/improve a model of participation of the CS in state decisionmaking;

2) to explain the importance of participation of the CS in the leadership process and attract the CS as an equal member in this process; 
For the SA:

3) to be ready to delegate a part of its authority to the CS;

4) to open communication lines with the CS and deserve trust from the CS by positive results;

5) to determine a level of participation of the SA and delegation of authority to satisfy the CS and establish system balance (maintain national interests).

Awareness of the situation, openness of the system and estimation of results can determine an ability of the system for change. Shift a group mentality to individual values increases a role of a person. For instance, the Soviet mentality protects a collective and decreases the individual role. The wish of people to lead defines a level of delegation of leadership power between the SA and the CS. Thus, a new democratic governance model can be based on change of human perception, mentality and culture through explanation of importance of participation of the CS in governance.

The SA may be not ready to delegate its authority to the CS and, in its turn, the CS does not have enough knowledge and understanding how to use it properly. Also, one of the problems is lack of trust between the SA and the CS because they do not look equal. A social culture may define these relationships. Obsolete mental models do not allow establishing a new cultural format in order to adapt the system in time.

To change proportion of participation of the SA and the CS in leadership is difficult because of system inertia. A proper social archetype may provide Keq opt as a continuation of a previous archetype, but on the new level of deve- lopment. The national social archetype is formed based on geopolitical location of the system. Change of the environment forces adapting the system and neighbor systems and their archetypes. It is a system complex change. It means transformation of all types of social archetypes in order to provide equilibrium of the space as a combination of the system with the environment when $K_{e q} \rightarrow K_{\text {eq opt }}$.

A social archetype should facilitate the readiness of the CS to take part in the leadership and the DMP. A new type of social archetype should be developed through the process of learning of the environment and the system. Thus, a system ability to learn $\left(S_{a t l}\right)$ can be a characteristic of the system that also defines its effectiveness. $S_{\text {atl }}$ defines how smart the system is and $C p$ because the system determines when, who, and where should influence the system in order to maintain $K_{\text {eq opt }}$. The $S_{\text {atl }}$ defines how close the system is to the model of a learning organization. The level of participation of the CS in leadership, system openness, and feedback may define $S_{\text {atl }}$. The social archetype, organizational culture, a structure, and a leader can define these characteristic of the system. Thus, $L_{\text {sef }}=f\left(K_{\text {eq opt }}\left(C p, S_{a t l}\right)\right)$.

To increase $S_{\text {atl }}$ means to educate the system, both, the SA and the CS, by using different approaches such as media, development of high standards, innovations, courses, building a model of "whole of government", increased individual responsibility through creation of space of leadership participation through social nets, applying of new computer programs, and web nets. It creates a culture of a learning organization with immediate feedback, correc- 
tions, and adaptation. Moreover, the system should love learning. It means the leadership and members of the system have to enjoy this process and be creative with vision and openness for innovations. In spite of delegation of leadership power, the leader remains critical.

Also, $C p$ can correspond to a certain combination of convergent and divergent processes in thinking based on change and complexity of the environment and the system. For instance, a complex situation requires divergent process or increased $C p$. Lack of trust between the SA and the CS creates misunderstanding. To find a common language and an appropriate model of their relationships is matter of leadership based on social archetype, national and organizational culture. It forms a state leadership model that can increase or decrease Satl.

Knowledge and education for the CS can improve social consciousness to take part in state governance. Education centers, institutions, media, courses for the SA and the CS can increase their cooperation; governance effectiveness based on honesty and transparency. It makes the system survivable and competitive based on creativity, knowledge, abilities and skills of each member of the society. Ideally, it can create a synergy effect of development of the community based on one spirit, freedom, mutual support and a desire to work together.

To make the system effective requires its timely change. The most difficult is to change mental models that influence decisions. They are stable, long-life concepts that are based on beliefs and values. An ability to refuse from accepted norms in conditions of changeable envi- ronment is critical. People should revise mental models and, in many cases, refuse using previous experience. For example, an American state as a business system provides a stress-free approach to change norms because they do not support system effectiveness anymore. Everything is directed to maintain system effectiveness (interior and exterior state policies).

To change beliefs and values in Ukraine may be more difficult because of traditional conservative culture, mentality, and a closed enough state system. In spite of this, technological innovations facilitate changing of the environment and development of the system. It forces changing norms, behavior, and communication. In communication social groups adapt own vocabulary, emotions, gestures, appearance in order to be in equilibrium with the modern globalized international space. It is like creating a new common language. This process can influence on perceptions, values, and beliefs.

Furthermore, under an open informational space, e-governance and e-government [29] create conditions for e-democracy. "E-Governance is the use of information and communication technologies to support good governance" [30]. It makes the system open and adaptable through the process of learning. It influences relationships between the SA and the CS and decentralize the system. Also, a real leader may be replaced a virtual one who can be formed by the SA and the CS in the Internet space through the social communication networks.

Leadership process is a matter of system effectiveness based on balance between min and max limits in order 
to open or close the system in a certain degree. It means to keep the system on the edge of order and disorder for adaptation with saving system functionality. State leadership should apply proper leadership power, change leadership stiles and system structure. In other words, if a region requires a centralized power and a strong leader or decentralized power it should be recognized and implemented in the framework of the system and also subsystems (regions). In spite of this, in case on increased complexity of the environment the SA and the CS should be ready for cooperation based on delegation of leadership power in right time and in right place.

The model of delegation of state leadership power between the SA and CS (fig. 3) presents an algorithm to lead the system based on two conditions: 1) to maintain system balance based on providing of equilibrium between the system and the environment (to maintain $K_{\text {eq opt }}$ ) and 2) to achieve established goals of the system. If one of these conditions is not satisfied the leader based on three conditions [1) $K_{e q} \rightarrow K_{e q \text { min }}$; 2) $K_{e q} \rightarrow K_{e q \text { crt }}$; 3) $\left.K_{e q} \rightarrow K_{e q \text { max }}\right]$ has to delegate leadership power between the SA and the CS, change leadership power, styles, a structure of the system, and always increase $S_{\text {att }}$ Also, to balance ends, ways, and means in the framework of possible permissible risk is critical to lead the system successfully. Achievement by the system $K_{\text {eq opt }}$, as a key notion of the algorithm, can be determined by social satisfaction based on MOE and MOP.

Conclusions. The proposed model for delegation of leadership between the SA and the CS can help increase the efficiency of public administration. To make the governance effective need to satisfy two conditions (figure 3 ) in the

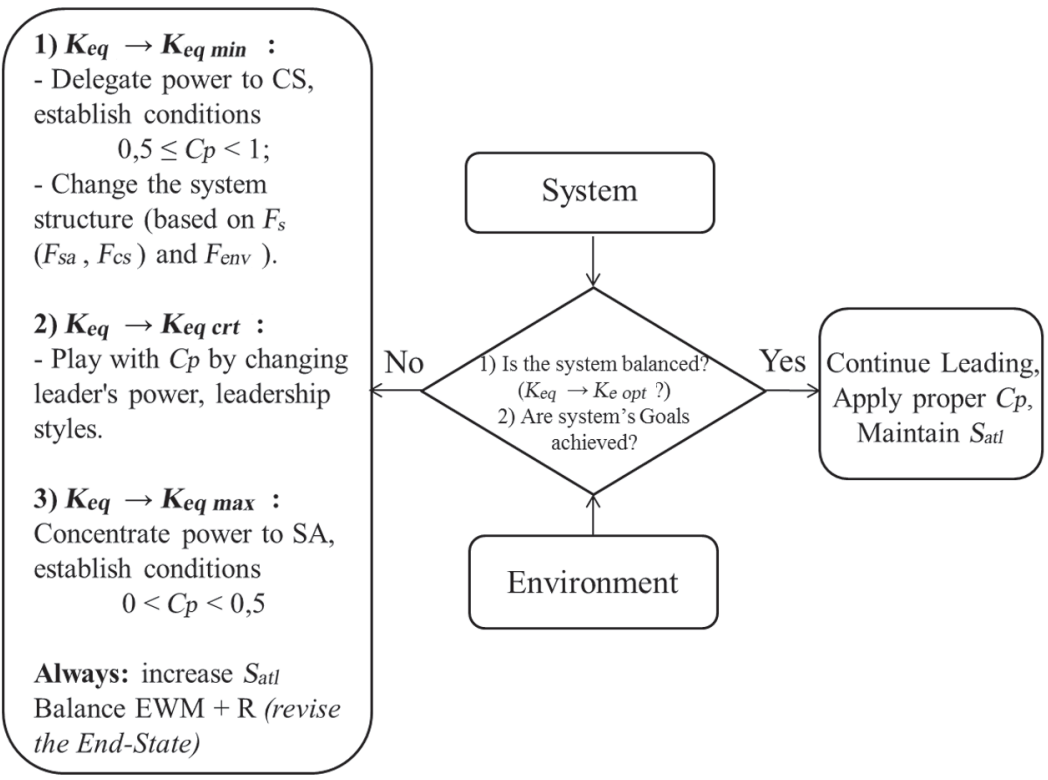

Fig. 3. A model of delegation of state leadership power

Source: created by the author. 
notional framework of the coefficient of dynamic equilibrium $-\left[K_{e q \text { min }}-\right.$ $\left.-K_{\text {eq crt }}-K_{\text {eq opt }}-K_{\text {eq } \max }\right]$. At first, it requires clear understanding of the system, the environment, the problem, and goals of the system. Second, the DMP requires participation both, the SA and the CS, but a fixed level of centralization or decentralization as a prescript rule may not be effective. The level of participation in the state leadership $(C p)$ and decentralization can depend on the conditions. Third, a state, as a system, should be similar to a model of a learning organization with flexible leadership based on mutual understanding between the SA and the CS. It means the system has to understand the need, time and degree of delegation of state power between the SA and the CS. In its turn, they should be actively involved in the PA to open the system enough through feedback and continuous communication based on clear announced and adapted to the environment national values, beliefs, unity of efforts and goals.

\section{REFERENCES}

1. Naplyokov Y. V. (2011). "Increasing unit effectiveness in a dynamic environment by implementing a leadership mathematical model". Master's Thesis, U.S. Army Command and General Staff College, CARL, Fort Leavenworth, KS 66027-2301, USA.

2. Pollitt Cristopher, Bouckaert Geert. (2011). Public management reform. A Comparative Analysis - New Public Management, Governance, and the Neo-Weberian State, third edition. New York: Oxford University Press.

3. Hoos J., Jenei G., Vass L. (2003). Public Administration and Public Manage- ment: Approaches and Reforms, In: Public Policy in Central and Eastern Europe: Theories, Methods, Practices, (eds.) M. Potucek, L. T. Leloup, G. Jenei, L. Varadi, NISPAcee.

4. Mitward H. B., Provan K. G. (2000). Governing the Hollow State. Journal of Public Administration Research and Theory 10 (2): 359-379.

5. Attila Agh. (2013). Europeanization of Public Administration in Eastern and Central Europe. Croatian and Comparative Public Administration, p. 739-762.

6. Tainter Joseph A. (1988). The nature of complex societies, New York: Cambridge University Press.

7. Utomo Tri, Widodo W. (2009). Balancing decentralization and deconcentration:emerging need for asymmetric decentralization in the unitary states. Graduate School of International Development Nagoya University. Jahan. Discussion Paper № 174.

8. Korzhenko V. V. (2016). "The phenomenon of philosophy as "Practical wisdom" of state governance", Theory and Practice of Public Administration, vol. 2 (53), p. 1-7.

9. Geert Bouckaert, Mzia Mikeladze. (2009). The NISPAcee Journal of Public Administration and Policy, vol. I, № 2, winter 2008/2009.

10. Maslow A. H. (1943). "A theory of human motivation." Psychological Review. 50 (4), p. 370-396.

11. Lenski G. E. (1966). Power and Privilege. A Theory of Social Stratification. New York: McGraw-Hill.

12. Childe Gordon V. (1951). Social evolution. Publisher: Henry Schuman. Tianer Joseph, A. 2003. The nature of complex societies, Cambridge, UK: Cambridge University Press.

13. Haas Jonathon (1982). The Evolution of the Prehistoric State. Columbia University Press, New York. 
14. Strange J. (2005). Center of Gravity and Critical Vulnerabilities. Quantico, VA., USA, Marine Corps University, Defense automated printing service center [E-Reader Version]. Retrieved from: http://jfsc.ndu.edu/Portals/72/ Documents/JC2IOS/Additional Reading/3B_COG_and_Critical_ Vulnerabilities.pdf

15. Bielska T. V., Naplyokov Y. V. (2017). Maximum allowable risk in decisionmaking process. // Public Management. № 7 (2). p. 76-88. Retrieved from http://vadnd.org.ua/app/uploads/2017/07/Англ.pdf

16. Ashby Ross W. (1957). An Introduction to Cybernetics. Second Impression. London: Chapman \& Hall LTD.

17. Solovyov V. S. (1873-1877). Kryza zakhidnoi filosofii [The crisis of Western philosophy], 2nd ed, Book Society Prosvita. St. Petersburg, Russian Empire.

18. Sidoruk O. (2016). Detsentralizatsiia: rezul'taty, vyklyk i perspektyvy [Decentralization: Results, Challenges and Prospects], Analytical report. Democratic Initiative Foundation named after Ilk Kucheriv. Kyiv, Ukraine.

19. Senge P. M. (2006). The Fifth Discipline: The Art \& Practice of the Learning Organization. New York, N.Y.: Doubleday.

20. Gerras Stephen J. (2008). Thinking Critically about Critical Thinking: A Fundamental Guide for Strategic Leaders, Planner's Handbook for Operational Design.

21. Kyiv International Institute of Sociology. (2016). Decentralization and local self-government reform: results of the second wave of sociological research, Analytical report. December 2016.

22. Laboratory of legitimate initiatives. (2018). Shadow Report on Reforms of state service and PA in Ukraine in 2017. U.S. Aid. Kyiv.

23. Katrenko A. V., Parsternak O. V. (2015). "The problem of optimality in the the- ory and practice of decision-making", Visnyk Natsional'noho universytetu "L'vivs'ka politekhnika", vol. № 829, p. 359-373.

24. Naplyokov Y. V. (2018). "Changing of mental models for effective decision-making" // Public Management № 1 (11). p. 189-206. Retrieved from: http://vadnd.org.ua/ua/collection/

25. Naplyokov Y. V. (2014). "An Algorithm for Maintaining Dynamic Equilibrium to Achieve Strategic Goals.” Master's Thesis, U.S. Army War College, Carlisle Barracks, Pennsylvania 17013, USA.

26. Naplyokov Y. V. (2018). The archetypal foundations of value choice in the process of adaptation to the modern society // Public Management. № 4 (14). p. 171-183. Retrieved from: http:// pub-management.com/index.php/ about/article/view/109/94

27. Allen C. D. (2012). "Creative Thinking for Individuals and Teams." An essay on creative thinking for military professionals. U.S. Army War College. Retrieved from: http://www.au.af.mil/ au/awc/awcgate/army-usawc/allen_ creative_thkg_sr_ldrs.pdf

28. Headquarters, Department of the Army (2015), FM 6-0, Commander and Staff Organization and Operations. Washington, DC, USA, DOI: 104216-001.

29. Bernhard I. (2013). E-government and E-governance - Swedish Case Studies with Focus on the Local Level. Stockholm, Sweden: KTH, Royal Institute of Technology. Available at: https:// www.diva-portal.org/smash/get/ diva2:663249/FULLTEXT01.pdf

30. Heeks R. (2001). Building e-Governance for Development: A Framework for National and Donor Action. E-Government Working Paper Series, № 12. Available at: http://unpan1. un.org/intradoc/groups/public/documents/NISPAcee/UNPAN015485. pdf 


\section{СПИСОК ВИКОРИСТАНИХ ДЖЕРЕЛ}

1. Naplyokov Y. V. (2011). "Increasing unit effectiveness in a dynamic environment by implementing a leadership mathematical model". Master's Thesis, U.S. Army Command and General Staff College, CARL, Fort Leavenworth, KS 66027-2301, USA.

2. Pollitt Cristopher, Bouckaert Geert. (2011). Public management reform. A Comparative Analysis - New Public Management, Governance, and the Neo-Weberian State, third edition. New York: Oxford University Press.

3. Hoos J., Jenei G., Vass L. (2003). Public Administration and Public Management: Approaches and Reforms, In: Public Policy in Central and Eastern Europe: Theories, Methods, Practices, (eds.) M. Potucek, L. T. Leloup, G. Jenei, L. Varadi, NISPAcee.

4. Mitward H. B., Provan K. G. (2000). Governing the Hollow State. Journal of Public Administration Research and Theory 10 (2): 359-379.

5. Attila Agh. (2013). Europeanization of Public Administration in Eastern and Central Europe. Croatian and Comparative Public Administration, p. 739-762.

6. Tainter Joseph A. (1988). The nature of complex societies, New York: Cambridge University Press.

7. Utomo Tri, Widodo W. (2009). Balancing decentralization and deconcentration:emerging need for asymmetric decentralization in the unitary states. Graduate School of International Development Nagoya University. Jahan. Discussion Paper № 174 .

8. Korzhenko V. V. (2016). "The phenomenon of philosophy as "Practical wisdom” of state governance”, Theory and Practice of Public Administration, vol. 2 (53), p. 1-7.
9. Geert Bouckaert, Mzia Mikeladze. (2009). The NISPAcee Journal of Public Administration and Policy, vol. I, № 2, winter 2008/2009.

10. Maslow A. H. (1943). "A theory of human motivation." Psychological Review. 50 (4), p. 370-396.

11. Lenski G. E. (1966). Power and Privilege. A Theory of Social Stratification. New York: McGraw-Hill.

12. Childe Gordon V. (1951). Social evolution. Publisher: Henry Schuman. Tianer Joseph, A. 2003. The nature of complex societies, Cambridge, UK: Cambridge University Press.

13. Haas Jonathon (1982). The Evolution of the Prehistoric State. Columbia University Press, New York.

14. Strange J. (2005). Center of Gravity and Critical Vulnerabilities. Quantico, VA., USA, Marine Corps University, Defense automated printing service center [E-Reader Version]. Retrieved from: http://jfsc.ndu.edu/Portals/72/ Documents/JC2IOS/Additional Reading/3B_COG_and_Critical_ Vulnerabilities.pdf

15. Bielska T. V., Naplyokov Y. V. (2017). Maximum allowable risk in decisionmaking process. // Public Management. № 7 (2). p. 76-88. Retrieved from http://vadnd.org.ua/app/uploads $/ 2017 / 07 /$ Англ.pdf

16. Ashby Ross W. (1957). An Introduction to Cybernetics. Second Impression. London: Chapman \& Hall LTD.

17. Solozyov V. S. (1873-1877). Kryza zakhidnoi filosofii [The crisis of Western philosophy], $2^{\text {nd }}$ ed, Book Society Prosvita. St. Petersburg, Russian Empire.

18. Sidoruk O. (2016). Detsentralizatsiia: rezul'taty, vyklyk i perspektyvy [Decentralization: Results, Challenges and Prospects], Analytical report. Democratic Initiative Foundation named after Ilk Kucheriv. Kyiv, Ukraine.

19. Senge P. M. (2006). The Fifth Discipline: The Art \& Practice of the Learn- 
ing Organization. New York, N.Y.: Doubleday.

20. Gerras Stephen J. (2008). Thinking Critically about Critical Thinking: A Fundamental Guide for Strategic Leaders, Planner's Handbook for Operational Design.

21. Kyiv International Institute of Sociology. (2016). Decentralization and local self-government reform: results of the second wave of sociological research, Analytical report. December 2016.

22. Laboratory of legitimate initiatives. (2018). Shadow Report on Reforms of state service and PA in Ukraine in 2017. U.S. Aid. Kyiv.

23. Katrenko A. V., Parsternak O. V. (2015). "The problem of optimality in the theory and practice of decision-making", Visnyk Natsional'noho universytetu “L’vivs'ka politekhnika”, vol. № 829, p. 359-373.

24. Naplyokov Y. V. (2018). "Changing of mental models for effective decision-making" // Public Management № 1 (11). p. 189-206. Retrieved from: http://vadnd.org.ua/ua/collection/

25. Naplyokov Y. V. (2014). "An Algorithm for Maintaining Dynamic Equilibrium to Achieve Strategic Goals.” Master's Thesis, U.S. Army War College, Carlisle Barracks, Pennsylvania 17013, USA.
26. Naplyokov Y. V. (2018). The archetypal foundations of value choice in the process of adaptation to the modern society // Public Management. № 4 (14). p. 171-183. Retrieved from: http:// pub-management.com/index.php/ about/article/view/109/94

27. Allen C. D. (2012). "Creative Thinking for Individuals and Teams." An essay on creative thinking for military professionals. U.S. Army War College. Retrieved from: http://www.au.af.mil/ au/awc/awcgate/army-usawc/allen creative thkg_sr_ldrs.pdf

28. Headquarters, Department of the Army (2015), FM 6-0, Commander and Staff Organization and Operations. Washington, DC, USA, DOI: 104216-001.

29. Bernhard I. (2013). E-government and E-governance - Swedish Case Studies with Focus on the Local Level. Stockholm, Sweden: KTH, Royal Institute of Technology. Available at: https:// www.diva-portal.org/smash/get/ diva2:663249/FULLTEXT01.pdf

30. Heeks R. (2001). Building e-Governance for Development: A Framework for National and Donor Action. E-Government Working Paper Series, № 12. Available at: http://unpan1. un.org/intradoc/groups/public/documents/NISPAcee/UNPAN015485. pdf 